\title{
The Relationship between the Occupational Exposure of Trichloroethylene and Kidney Cancer
}

Inah $\mathrm{Kim}^{1,2}$, Jaehyeok Ha ${ }^{3}$, June-Hee Lee ${ }^{1,2}$, Kye-mook Yoo ${ }^{4}$ and Jaehoon Rho ${ }^{1,2,5^{*}}$

\begin{abstract}
Trichloroethylene (TCE) has been widely used as a degreasing agent in many manufacturing industries. Recently, the International Agency for Research on Cancer presented "sufficient evidence" for the causal relationship between TCE and kidney cancer. The aim of this study was to review the epidemiologic evidences regarding the relationship between TCE exposure and kidney cancer in Korean work environments. The results from the cohort studies were inconsistent, but according to the meta-analysis and case-control studies, an increased risk for kidney cancer was present in the exposure group and the dose-response relationship could be identified using various measures of exposure. In Korea, TCE is a commonly used chemical for cleaning or degreasing processes by various manufacturers; average exposure levels of TCE vary widely. When occupational physicians evaluate work-relatedness kidney cancers, they must consider past exposure levels, which could be very high (>100 ppm in some cases) and associated with jobs, such as plating, cleaning, or degreasing. The exposure levels at a manual job could be higher than an automated job. The peak level of TCE could also be considered an important exposure-related variable due to the possibility of carcinogenesis associated with high TCE doses. This review could be a comprehensive reference for assessing work-related TCE exposure and kidney cancer in Korea.
\end{abstract}

Keywords: Trichloroethylene, Kidney cancer, Korea, Work-related, Occupation, Exposure

\section{Introduction}

Trichloroethylene (TCE) has been widely used as a degreasing agent in many manufacturing industries (i.e., metal processing or electronic device production) due to its lipid solubility, volatility, no flammability, and economic efficiency [1]. TCE is a well-known carcinogen according to animal studies. The reactive metabolites of the glutathione pathway and the oxidation process of TCE could have carcinogenic effects in kidney and liver or lung, respectively [2].

Recently, the International Agency for Research on Cancer (IARC) categorized TCE as a Group 1 carcinogen and stated that there is "sufficient evidence" for the causal relationship between TCE and kidney cancer [3]. According to increasing epidemiologic evidences, the first work-related case of kidney cancer in Korea was

\footnotetext{
* Correspondence: jhroh@yuhs.ac

${ }^{1}$ Department of occupational health, Yonsei University Graduate School of

Public Health, Seoul, Korea

${ }^{2}$ Institutes for Occupational Health, Yonsei University College of Medicine, Seoul, Korea

Full list of author information is available at the end of the article
}

reported in 2013 [4]. TCE is still widely used as degreasing or cleansing agents and high exposure levels of TCE could be prevalent in Korea. Moreover, the prevalence or incidence of target cancers associated with TCE (i.e., kidney cancer) has rapidly increased in the Korean population [5].

The aim of this study was to review the epidemiologic evidences regarding the relationship between TCE exposure and kidney cancer in the working population in Korea.

\section{Review}

Incidence and risk factors of kidney cancer

According to the national cancer statistics, the agestandardized incidence rate of kidney cancer per 100,000 persons increased from 3.1 in 1999 to 3.5, 4.9, 5.4, 7.3, and 8.0 in 2002, 2005, 2006, 2010, and 2011, respectively. Kidney cancer had the third most rapid increase (6.2\%), following thyroid (23.7\%) and prostate (13.5\%) cancers; but the incidence of esophageal, stomach, laryngeal, and cervical cancers decreased from 1999 to 2011. The annual percentage change over time, expressed as 
$(\exp (b)-1) \times 100$, where $b$ was the estimated slope of a linear regression from a logarithmic scaled agestandardized incidence rate and calendar year, was statistically significant in both genders. In 2011, the crude incidence rate of kidney cancer per 100,000 men was 10.9 (2,722 cases), which was the $9^{\text {th }}$ most common cancer among Korean men, following cancers of the stomach, colon or rectum, lung, liver, prostate, thyroid, bladder, and pancreas (Table 1). The incidence of kidney cancer increased with age, but the incidence was found to be the highest for people $\geq 70$ years, which was $44.5 / 100,000$ for men and 16.5/ 100,000 for women (Table 2) [5]. The subtypes of renal cell cancer (RCC) were divided into the clear cell type, papillary type, chromophobe type, and collecting duct type. Currently, there is limited evidence to indicate that occupational risk factors increase RCCs of a specific subtype.

The risk factors for RCC include smoking, obesity, a past history of renal stones [6], and the presence of a genetic mutation known as Von Hippel-Lindau syndrome, which is present in $1 / 3 \sim 1 / 2$ patients [7]. Various metals (i.e., arsenics, cadmium, lead, or uranium), poly-aromatic hydrocarbons, solvents (i.e., chlorinated hydrocarbons), and asbestos have been considered as occupational risk factors for RCC in several studies [8]. According to the IARC, TCE has sufficient evidence while arsenic and inorganic arsenic compounds, cadmium

Table 1 Crude incidence rate (CR) and age-standardized incidence rate (ASR) of kidney cancer per 100,000 persons from 1999 to 2011 in Korea

\begin{tabular}{|c|c|c|c|c|c|c|}
\hline & \multicolumn{2}{|c|}{ Total } & \multicolumn{2}{|c|}{ Men } & \multicolumn{2}{|c|}{ Women } \\
\hline & CR & ASR & CR & ASR & CR & ASR \\
\hline 1999 & 3.0 & 3.1 & 4.1 & 4.7 & 1.9 & 1.7 \\
\hline 2000 & 3.0 & 3.0 & 4.1 & 4.6 & 1.9 & 1.8 \\
\hline 2001 & 3.5 & 3.4 & 4.7 & 5.1 & 2.2 & 2.0 \\
\hline 2002 & 3.6 & 3.5 & 5.0 & 5.2 & 2.3 & 2.1 \\
\hline 2003 & 3.9 & 3.6 & 5.3 & 5.4 & 2.5 & 2.2 \\
\hline 2004 & 4.3 & 3.9 & 5.8 & 5.7 & 2.8 & 2.4 \\
\hline 2005 & 4.9 & 4.2 & 6.6 & 6.3 & 3.1 & 2.5 \\
\hline 2006 & 5.4 & 4.6 & 7.4 & 6.8 & 3.5 & 2.7 \\
\hline 2007 & 6.0 & 5.0 & 8.3 & 7.4 & 3.7 & 2.9 \\
\hline 2008 & 6.6 & 5.2 & 9.0 & 7.8 & 4.1 & 3.1 \\
\hline 2009 & 7.0 & 5.5 & 9.4 & 7.9 & 4.5 & 3.3 \\
\hline 2010 & 7.3 & 5.5 & 10.1 & 8.3 & 4.3 & 3.1 \\
\hline 2011 & 8.0 & 6.2 & 10.9 & 8.6 & 5.1 & 3.6 \\
\hline $\mathrm{APC}^{*}$ & & K0.05) & & $<0.05)$ & & $<0.05)$ \\
\hline
\end{tabular}

*APC; Annual Percentage Change, expressed as $(\exp (b)-1) \times 100$, where $b$ is the estimated slope of a linear regression from a logarithmic scaled age-standardized rates and calendar years. and its compounds, and printing processes have limited evidences for kidney cancer in humans [8].

\section{Occupational exposure of trichloroethylene in Korea Work environment survey in manufacturers in 2004}

According to work environment survey for manufacturers, the annual amount of TCE usage was 7849 tons; 1982.4 tons by manufacturers of motor vehicles, trailers and semitrailers, 1085.9 tons by manufacturers of fabricated metal products, except machinery and furniture, 1056.4 tons by manufacturers of electric components, computer, radio, television, and communication equipment and apparatuses, and 483.8 tons by manufacturers of machinery and equipment. TCE was mostly used as a cleaning agent. About 5,949 workers in 1,540 companies could have been exposed to TCE during production processes in 2004 [9].

\section{A survey on the status of using trichloroethylene}

After 2 employees had died from Steven Johns syndrome related to TCE exposure in 2006, a survey on the distribution and usage of TCE was conducted using a database to work environment monitoring of the representative 103 companies. TCE was mostly used by manufacturers of motor vehicle and engine parts and accessories (23,920 L). The personal ambient exposure levels in this survey ranged from non-detectable (ND) to $49.87 \mathrm{ppm}$. The range of ambient exposure level of TCE was ND 49.87 ppm in manufacturers of motor vehicle and engine parts and accessories, 0.08 41.55 ppm in manufacturers of electric components, computer, radio, television, and communication equipment and apparatuses, and ND 30.80 ppm in manufacturers of fabricated metal products, except machinery and furniture (Table 3). Workers engaging in manual tasks or semi-automated processes were more frequently exposed to TCE than those who worked with automated processes (87\% vs. 13\%) [10].

\section{Work environment monitoring}

The analysis of ambient exposure levels (time weighted average (TWA) from 8 hours) of TCE from the work environment monitoring (WEM) in the manufacturing industries conducted by private occupational health organizations during 2002-2010 is shown in Table 4. A total of 33,652 samples were analyzed and we reclassified the task categories to 22 from 537. The range of the geometric mean (GM) was 0.00015 0.25311 ppm. The exposure level of TCE was highest during plating $(0.25311 \mathrm{ppm})$, followed by cleaning $(0.16013 \mathrm{ppm})$ and degreasing $(0.04185 \mathrm{ppm})$. The highest exposure level of TCE by personal sampler was 598 ppm for cleaning, followed by 237 ppm for assembly, 154 ppm for coating, $152 \mathrm{ppm}$ for degreasing, and $148 \mathrm{ppm}$ for painting. The median exposure levels of TCE were 3.18 ppm, 2.33 ppm, 
Table 2 Trends in kidney cancer incidence rates in Korea (per 100,000 persons)

\begin{tabular}{|c|c|c|c|c|c|c|c|c|c|c|c|c|c|c|}
\hline \multirow[b]{2}{*}{ Age (years) } & \multicolumn{7}{|c|}{ Men } & \multicolumn{7}{|c|}{ Women } \\
\hline & 2002 & 2003 & 2004 & 2005 & 2009 & 2010 & 2011 & 2002 & 2003 & 2004 & 2005 & 2009 & 2010 & 2011 \\
\hline $0-9$ & 0.6 & 0.6 & 0.7 & 0.6 & 0.8 & 0.9 & 0.8 & 0.8 & 0.5 & 0.5 & 0.6 & 0.6 & 0.7 & 0.7 \\
\hline 10-19 & 0.0 & 0.1 & 0.3 & 0.1 & 0.1 & 0.1 & 0.1 & 0.0 & 0.1 & 0.0 & 0.1 & 0.1 & 0.1 & 0.2 \\
\hline $20-29$ & 0.4 & 0.4 & 0.4 & 0.6 & 0.8 & 0.7 & 0.7 & 0.4 & 0.3 & 0.3 & 0.3 & 0.6 & 0.3 & 0.6 \\
\hline $30-39$ & 1.9 & 2.0 & 2.1 & 2.2 & 3.8 & 3.9 & 4.3 & 0.9 & 1.2 & 1.1 & 1.0 & 1.3 & 1.7 & 2.1 \\
\hline $40-49$ & 5.4 & 6.7 & 6.5 & 7.1 & 9.4 & 9.8 & 10.3 & 1.9 & 3.0 & 3.0 & 2.5 & 4.1 & 3.7 & 4.0 \\
\hline 50-59 & 13.7 & 13.0 & 12.4 & 15.0 & 18.4 & 20.5 & 21.1 & 5.3 & 4.3 & 6.3 & 5.6 & 8.1 & 7.7 & 8.5 \\
\hline $60-69$ & 22.7 & 23.2 & 24.7 & 24.5 & 31.8 & 33.1 & 33.6 & 8.1 & 8.9 & 8.1 & 10.1 & 12.8 & 12.3 & 13.5 \\
\hline$\geq 70$ & 26.2 & 25.4 & 32.4 & 36.5 & 42.2 & 41.5 & 44.5 & 9.6 & 9.5 & 9.8 & 13.0 & 15.3 & 13.6 & 16.5 \\
\hline
\end{tabular}

and $2.01 \mathrm{ppm}$ for plating, cleaning, and degreasing, respectively. As a result, cleaning, degreasing, and plating could be high-risk jobs for TCE exposure.

\section{Reliability of work environment monitoring}

Considering the limitation of the reliability or validity of WEM, we analyzed reports from 16 enterprises, which were assessed for the reliability of WEM by the Korea Agency for Occupational Safety and Health for cleaning jobs, which were the most common jobs in 2006. The highest level of TCE exposure was $116.62 \mathrm{ppm}$ in manufacturers of non-metallic mineral products (i.e., press and cleaning), followed by manual cleaning for optic device production (114.41 ppm), degreasing for rubber goods production (88.84 ppm), and cleaning for transport machineries and equipment production (49.86 ppm; Table 5).

\section{Peer-reviewed and published papers in Korea}

According to peer-reviewed and published papers in Korea, the exposure level of TCE in the period from 1970 s' to 1980 s' was higher than that in recent periods. Paik et al. reported that the exposure levels of TCE in
1970 , were $110 \mathrm{ppm}$ in the corners of the cleaning room, $124 \mathrm{ppm}$ in regions where cleaning is initiated, and 221 301 ppm in regions where cleaning is terminated [11]. Kim et al. also reported that the exposure levels of TCE during the plating process in 1989: 19.8 50.3 ppm in the cleaning bath and 130.8 456.2 ppm in the drying bath [12]. The personal ambient exposure level of TCE for manual cleaning workers was $83.5 \mathrm{ppm}$ and the regional ambient exposure level of TCE for manual polishing workers was 35.5 in 1989. At that time, the percentage of enterprises with ambient exposure levels higher than the occupational exposure limit set by the government (i.e., $75 \mathrm{ppm}$ ) was $54.2 \%$ in 1989 [13]. The GM of the 8 hours' TWA for degreasing workers was $26 \mathrm{ppm}$ and the range of the exposure level was 1.4 123 ppm. The GM of the 8 hours' TWA for workers who assisted with cleaning was $11 \mathrm{ppm}$ (range = $0.5 \sim 59 \mathrm{ppm})$ in 1994 [14]. In 1994, the GM of the 8 hours' time weighted exposure level of workers using TCE was 9.9 35.3 ppm; 14.2\% of workers had exposure levels above the occupational exposure limit set by the government [15]. The exposure level of workers who engaged in semi-automated cleaning was $<1$ ppm in 1995,

Table 3 Exposure status according to trichloroethylene use in $\mathbf{2 0 0 6}$ in Korea

\begin{tabular}{lrrrr}
\hline Type of industry & No. of factories & No. of workers & Amount used (L/month) & Concentration range (ppm) \\
\hline Total & 103 & 390 & 87,320 & - \\
Chemical & 3 & 19 & 4,116 & $0.97 \sim 13.26$ \\
Plastics \& rubber products & 1 & 35 & 6,830 & ND 42.63 \\
Primary metal & 6 & 18 & 6,787 & $2.91 \sim 37.35$ \\
Fabricated metal products & 24 & 59 & 11,990 & ND 30.80 \\
Machinery & 18 & 59 & 3,950 & ND 48.48 \\
Computer \& electronic products & 9 & 62 & 19,596 & $0.08 \sim 41.55$ \\
Electrical equipment, appliance & 10 & 56 & 4,771 & ND 21.29 \\
Transportation equipment & 18 & 30 & 23,920 & ND 49.87 \\
Others & 14 & 52 & 5,360 & ND 39.51 \\
\hline
\end{tabular}

ND; Non-detectable, concentration level was lower than the detection limit.

(Source: Cho et al. 2007) [10]. 
Table 4 Exposure levels of trichloroethylene by Korean manufacturing industry jobs according to the regular work environment measurement (2002 2010)

\begin{tabular}{|c|c|c|c|c|c|}
\hline Job & No. of samples & Arithmetic mean (ppm) & Median (ppm) & Geometric mean (ppm) & Maximum (ppm) \\
\hline Cleaning & 8,374 & 8.953 & 2.33495 & 0.16013 & 598 \\
\hline Degreasing & 421 & 7.780 & 2.01080 & 0.04185 & 152 \\
\hline Assembly & 1,146 & 2.850 & 0.08975 & 0.00101 & 237 \\
\hline Adhesion & 700 & 1.044 & 0.16850 & 0.00172 & 29 \\
\hline Coating & 671 & 3.250 & 0.48790 & 0.01499 & 154 \\
\hline Painting & 3,713 & 1.326 & 0.00000 & 0.00015 & 148 \\
\hline Processing & 1,046 & 3.955 & 0.41855 & 0.01159 & 108 \\
\hline Inspection & 890 & 2.704 & 0.59650 & 0.01061 & 94 \\
\hline Printing & 1,519 & 1.948 & 0.17800 & 0.00518 & 65 \\
\hline Soldering & 802 & 2.053 & 0.42860 & 0.00881 & 50 \\
\hline Plating & 399 & 8.508 & 3.17970 & 0.25311 & 63 \\
\hline Molding & 507 & 4.545 & 0.71700 & 0.01194 & 60 \\
\hline Laboratory & 317 & 0.692 & 0.00000 & 0.00006 & 48 \\
\hline Impregnation & 199 & 7.697 & 0.18200 & 0.00839 & 185 \\
\hline Mixing & 511 & 1.807 & 0.09700 & 0.00111 & 54 \\
\hline Heat treatment & 201 & 4.982 & 1.00000 & 0.01987 & 64 \\
\hline Plugging & 34 & 0.565 & 0.08136 & 0.00063 & 8 \\
\hline Infusion & 267 & 5.846 & 0.40630 & 0.01467 & 270 \\
\hline Reaction & 138 & 0.461 & 0.00000 & 0.00005 & 6 \\
\hline Packing & 273 & 2.128 & 0.27600 & 0.00597 & 45 \\
\hline Cast & 124 & 2.601 & 0.04165 & 0.00060 & 43 \\
\hline Others & 11,400 & 9.318 & 0.27935 & 0.00540 & 1,471 \\
\hline Total & 33,652 & 6.497 & 0.40790 & 0.00840 & - \\
\hline
\end{tabular}

but the peak exposure level of TCE (100 ppm) occurred during the replacement of the TCE solution, which was performed once per week. However, the ambient exposure level of TCE for manual cleaning workers was 107 ppm [16].

\section{Scientific evidences for the causal relationship between trichloroethylene exposure and kidney cancer Meta-analysis}

The first meta-analysis was reported in 2011 and included 24 cohort and case-control studies; in the TCE exposed group, the relative risk (RR) was 1.27 and the $95 \%$ confidence interval $(\mathrm{CI})$ was $1.13 \sim 1.43$. The RR of higher exposure group was 1.58 (95\% CI = 1.28 1.96) and the strength of association increased in the higher exposure group compared to the lower exposure group [17]. The second meta-analysis, which included 15 cohort and 13 case-control studies, was conducted during 1950 2011 and was published in 2012. In the second analysis, the RR for kidney cancer from the cohort studies, case-controlled studies, and the pooled RR of all studies was $1.26(95 \% \mathrm{CI}=1.02 \sim 1.56), 1.35$ (95\% CI = $1.17 \sim 1.57$ ), and 1.32 (95\% CI = 1.17 1.50), respectively.
The authors of this study concluded that significant and strong associations were consistent among the studies to measure exposure levels and also emphasized the possibility of underestimating risk due to the misclassification of exposure (i.e., exposure to TCE was usually broadly measured with exposure to chlorinated hydrocarbon or other organic solvents) [18]. This was a reasonable conclusion considering that differences in carcinogenicity among halogenated hydrocarbons; unsaturated shortchain halogenated hydrocarbons were identified to have carcinogenic effects in animal studies. TCE, an unsaturated short-chain hydrocarbon, has carcinogenic effects, but trichloroethane, which is similar to TCE in chemical structure, is saturated and is not carcinogenic [19].

\section{Cohort studies}

Most studies regarding the association between TCE exposure and kidney cancer were conducted in aerospace workers in the United States and Demark by measuring their exposure level using a job-exposure matrix (JEM) based on the job name or code. Zhao et al. reported a significant RR (4.90, 95\% CI = 1.23 19.60) of incidence in only the high exposure group, which consisted of 


\begin{tabular}{|c|c|c|c|c|}
\hline Industry in manufacturer & Job1 & Job2 & Method & Range of concentration (ppm) \\
\hline $\begin{array}{l}\text { Electronic components } \\
\text { (LCD panel frame) }\end{array}$ & Press & Processing \& cleaning & $\begin{array}{l}\text { Solid sampler. NIOSH } \\
\text { method } 1022\end{array}$ & $8.258 \sim 11.995$ \\
\hline $\begin{array}{l}\text { Power electric equipment } \\
\text { (painting transformers) }\end{array}$ & $\begin{array}{l}\text { Storing component \& } \\
\text { cleaning }\end{array}$ & Printing \& cleaning & $\begin{array}{l}\text { Solid sampler. NIOSH } \\
\text { method } 1022\end{array}$ & $\begin{array}{l}\text { Painting and cleaning: } \\
0.343 \sim 9.742 \text { masking: } \\
\text { 1.099 16.432, touch up: } \\
0.149 \sim 2.462\end{array}$ \\
\hline $\begin{array}{l}\text { Measuring, optic and } \\
\text { precision instrument }\end{array}$ & Press \& cleaning & Grinding \& cleaning & $\begin{array}{l}\text { Solid sampler. } \\
\text { diffusive sample }\end{array}$ & $\begin{array}{l}\text { 16.99 114.41 } \\
\text { (including manual work) }\end{array}$ \\
\hline $\begin{array}{l}\text { Television and communication } \\
\text { equipment }\end{array}$ & Press molding \& processing & Assembly \& cleaning & $\begin{array}{l}\text { Solid sampler. NIOSH } \\
\text { method } 1022\end{array}$ & $\begin{array}{l}85.44 \text { in manual } \\
\text { (closed } 1 \text { years ago), } \\
2.16 \sim 3.75 \text { in automatic }\end{array}$ \\
\hline Optic equipment and lens & Cutting & Cleaning & $\begin{array}{l}\text { Solid sampler. NIOSH } \\
\text { method } 1022\end{array}$ & 52.90 (in indoor) \\
\hline $\begin{array}{l}\text { Parts and accessories } \\
\text { for motor vehicle }\end{array}$ & Assembly \& dipping & Bonding \& cleaning & Sorbent tube & $11.57 \sim 18.52$ \\
\hline Electronic components & Press & Cleaning & Sorbent tube & $31.72 \sim 49.86$ \\
\hline Textile & Degummed and twist thread & Decontamination & Sorbent tube & $0.14 \sim 1.38$ \\
\hline \multirow[t]{2}{*}{ Plating } & \multirow[t]{2}{*}{$1^{\text {st }}$ cleaning } & \multirow[t]{2}{*}{ 2nd cleaning } & \multirow[t]{2}{*}{ Sorbent tube } & 1st cleaning: $28.59,3.55$ \\
\hline & & & & 2nd cleaning: 39.28, 1.81 \\
\hline Metal tooling & Press & Cleaning & $\begin{array}{l}\text { Solid sampler. NIOSH } \\
\text { method } 1022\end{array}$ & $8.75 \sim 9.22$ \\
\hline $\begin{array}{l}\text { Parts and accessories } \\
\text { for motor vehicle }\end{array}$ & Mixing \& surface treatment & Degreasing & $\begin{array}{l}\text { KOSHA CODE-A-1-2004 } \\
\text { (Method No. 016) }\end{array}$ & 2.56 \\
\hline Other electric equipment & Wring \& dipping & Assembly \& impregnation & $\begin{array}{l}\text { KOSHA CODE-A-1-2004 } \\
\text { (Method No. 016) }\end{array}$ & $0.03 \sim 0.05$ \\
\hline Rubber goods production & Preparation & Degreasing & $\begin{array}{l}\text { KOSHA CODE-A-1-2004 } \\
\text { (Method No. 016) }\end{array}$ & $15.49 \sim 88.84$ \\
\hline Other metal product & Press and spot welding & Cleaning & $\begin{array}{l}\text { KOSHA CODE-A-1-2004 } \\
\text { (Method No. 016) }\end{array}$ & $7.21 \sim 11.7$ \\
\hline $\begin{array}{l}\text { Transport machineries } \\
\text { and equipment }\end{array}$ & Press and spot welding & Cleaning & $\begin{array}{l}\text { KOSHA CODE-A-1-2004 } \\
\text { (Method No. 016) }\end{array}$ & $14.90 \sim 49.83$ \\
\hline Non-metallic mineral product & Melting \& extrusion & Press \& cleaning & $\begin{array}{l}\text { KOSHA CODE-A-1-2004 } \\
\text { (Method No. 016) }\end{array}$ & $41.32 \sim 116.62$ \\
\hline
\end{tabular}

5,049 male aerospace workers who work for $>2$ years during 1950 1993 and were followed during 1988 2000 [20]. In manual workers who worked $>5$ years and used TCE in Denmark, the RR was 1.5 (95\% CI = 1.1 2.2) [21]. Although the RRs in the early cohort study [22] and other subgroups in the same cohorts were statistically insignificant, the dose-response relationship between the risk for kidney cancer and TCE exposure was also identified (Table 6) [20-23].

Inconsistencies in the results from the cohort studies could be due to risk underestimation (i.e., nondeferential misclassification of exposure). Most of the authors of the cohort studies measured exposure-related variables using the JEM, which is a type of ecological exposure indicator, and assumed that the exposure level would be consistent for the same job. These inconsistencies could lead to the misclassification of exposure and decreased statistical power in their results.

\section{Case-control studies}

The main results of the case-control studies are presented in Table 6. According to the case-control studies, consistent associations and dose-response relationships were observed after adjusting for various confounding variables. A review of the classification of exposure levels in individual research papers was important to fully evaluate work-related TCE exposures. According to a recent study by Moor et al., the risk of kidney cancer in the exposure group was twice as high as the nonexposure group. A dose-response relationship was identified in this study; the odds ratio (OR) of the exposed group $<13.5$ years was 1.89 (95\% CI $=0.84 \sim 4.28)$ and $\geq 13.5$ years was $2.25(95 \% \mathrm{CI}=0.95 \sim 5.29)$. If the total exposure time was $<1080$ hours, the OR of the exposed group was $1.22(95 \% \mathrm{CI}=0.48 \sim 3.12)$; if the exposure time was $\geq 1080$ hours, the OR was 2.86 (95\% CI = 1.31 6.23). An exposure time of 1080 hours is about 27 
Table 6 Summary of risk measurement of the major cohort and case-control studies

\section{Authors, (years) \\ Study subjects/design \\ Exposure measurement}

Moore et al. (2010) [24] Hospitals in 4 European countries ( $n=1,097)$

Czech Republic, Poland, 1999-2003; hospital controls with diagnoses

Romania, Russia

unrelated to smoking or genitourinary

disorders $(n=1,476) /$ case-control

Chabotel et al. (2006)

[25] France

\section{RCC ( $n=87)$ from urologists' files and area} teaching hospitals, 1993-2003; urologist or general practitioner patient controls $(n=316) /$ case-control
Specialized job-specific questionnaire for specific

obs or industries of interest focused on TCE with exposure assignment by frequency and confidence of TCE exposure

\section{Overall OR or RR}

63 (1.04-2.54) for all subjects

2.05 (1.13-3.73) for high-confidence assessments only

64 (0.95-2.84) for full study;

Semi-quantitative cumulative TCE exposure and presence/absence of peak TCE exposure assigned to subjects using a JEM designed using information obtained from questionnaires and routine

atmospheric monitoring of workshops or biological monitoring (U-TCA) of workers carried out since the 1960s.
ORs or RRs according to

exposure level

Duration

$<13.5$ yrs: $1.89(0.84-4.28)$ $\geq 13.5$ yrs: $2.25(0.95-5.29)$ $<1080$ hrs: $1.22(0.48-3.12)$ $\geq 1080$ hrs: $2.86(1.31-6.23)$

Cumulative

$<1.58$ ppm.yr: $1.77(0.64-4.80)$

$\geq 1.58$ ppm.yr: $2.23(1.07-4.64)$

Average intensity

$<0.076$ ppm: $1.73(0.75-4.02)$

$\geq 0.076$ ppm: 2.41 (1.05-5.56)

*reference group: non-exposed

High cumulative level: 3.34

(1.27-8.74)

ppm.yrs

1-154: $0.85(0.10-7.41)$

155-335: $1.03(0.29-3.70)$

>335: 3.34 (1.27-8.74)

peak + cumulative leve

(-)/low-medium: 0.90 (0.27-3.01)

$(+) /$ low-medium: 1.34 (0.13-14.0)

(-)/high: 2.74 (0.66-11.4)

(+)/high: 3.80 (1.27-11.4)

with 10-yr lag

high: $2.16(1.01-4.65)$

+peaks: 3.15 (1.19-8.38)

mortality medium: 0.85 (0.15-4.93) \& 1.69 (0.29-9.70) with 20-yrs lag

high: $0.96(0.09-9.91) \& 1.82$ (0.09-38.6) with 20-yrs lag

incidence medium: $1.26(0.26-6.14)$ \& $1.19(0.22-6.40)$ with 20-yrs lag

high: $7.71(0.65-91.4) \& 7.40$

(0.47-116) $\mathrm{n}=5,049)$ /cohort related with JEM and al,

intensity scores 
Table 6 Summary of risk measurement of the major cohort and case-control studies (Continued)

Brüning et al. (2003) Histologically confirmed RCC $(n=134)$, from Self-reported exposure duration using JEM

[26] Germany

hospitals, 1992-2000; hospital controls

$(n=401) /$ case-control

Raaschou-Nielsen et al. Blue-collar workers employed $>1,968$ at

(2003) Denmark

347 TCE-using companies $(n=40$

with

duration of employment, yrs of $1^{\text {st }}$ employment

at a TCE-using company, number of employees

Follow up to $1997 /$ cohort

Pesch et al. (2000) Histologically confirmed RCC from hospitals

[27] Germany 5 regions) $(n=935), 1991-1995 ;$ controls randomly selected from residency registries ( $n=4,298)$ /case-control

TCE and other exposures assigned by

questionnaire, assessed occupational history

using job title (JEM approach)

$1.20(0.94-1.50)$

$1.24(1.03-1.49)$

(a)

$<10$ yr: 3.78 (1.54-9.28)

10-<20 yr: 3.78 (1.54-9.28)

$\geq 20$ yr: 2.69 (0.84-8.66)

$\geq 5$ years all subject: $1.6(1.1-2.2)$ in

subcohort with expected higher

exposure levels: 1.7 (1.1-2.4)

substantial exposure

men: $1.3(0.8-2.1)$

women: 1.8 (0.6-5.0)

high exposure men: $1.1(0.8-1.5)$

women: 1.8 (0.6-1.9)

medium exposure

men: 1.3 (1.0-1.8)

women: $1.3(0.7-2.6)$

High cumulative exposure score: $1.59(0.68-3.71)$ 
weeks or 6 months for a 40-hour work-week. A doseresponse relationship could be identified for the cumulative exposure level; the ORs were $1.77(95 \% \mathrm{CI}=$ $0.64 \sim 4.80)$ and $2.23(95 \% \mathrm{CI}=1.07 \sim 4.64)$ for $<1.58 \mathrm{ppm}$. year and $\geq 1.58 \mathrm{ppm}$ 'year, respectively. The ORs of the average exposure level was $1.73(95 \% \mathrm{CI}=0.75 \sim 4.02)$ and $2.41(95 \% \mathrm{CI}=1.05 \sim 5.56)$ for $<0.0076 \mathrm{ppm}$ and $\geq 0.0076$ $\mathrm{ppm}$, respectively, compared with the non-exposure group [24]. Therefore, kidney cancer can possible develop in people with a low cumulative exposure level or a short exposure duration.

In 2006, Charbotel et al. reported the results from case-control studies based on 87 RCC cases and 316 control groups in France. The cumulative exposure levels of TCE were divided into the following 3 groups: low exposure group (1 155 ppm.year), medium exposure group (155 355 ppm.year), and high exposure group ( $>335 \mathrm{ppm} \cdot$ year). The ORs were determined to be $3.34(95 \% \mathrm{CI}=1.27 \sim 8.74), 1.03(95 \% \mathrm{CI}=0.29 \sim 3.70)$, and $0.85(95 \% \mathrm{CI}=0.10 \sim 7.41)$ in the high, medium, and low exposure groups, respectively. Peak exposure was defined as being exposed to $200 \mathrm{ppm}$ of TCE for $>15$ minutes. The OR for peak exposure was 3.80 (95\% CI $=1.27 \sim 11.40)$ [25].

In an earlier case-control study, Brüning et al. evaluated occupational exposure levels of TCE in 134 kidney cancer cases and 401 controls from 1992 2000; the OR of the exposed group was $1.80(95 \% \mathrm{CI}=1.01 \sim 3.20)$, and the OR of workers involved with cutting and cleaning was $5.57(95 \% \mathrm{CI}=2.33 \sim 13.32)$. The OR of the exposure group $<10$ years, 10 20 years, and $>20$ years of exposure was $3.78(95 \% \mathrm{CI}=1.54 \sim 9.28), 1.80(95 \% \mathrm{CI}=$ $0.67 \sim 4.79$ ), and 2.69 (95\% CI $=0.84 \sim 8.66$ ), respectively [26]. Pescht et al. also presented statistically significant increase of OR [27].

In some studies, the possibility of a high-dose phenomenon or genetic sensitivity related to TCE exposure and the risk of kidney cancer has been reported. Therefore, renal tubule toxicity would be more important than genetic toxicity for carcinogenesis. A history of peak exposures was the most important variable related to exposure in another study [28]. The presence of a genetically susceptible population for which the glutathione S-transferase theta 1 enzyme was active has also been reported in a case-controlled study [24].

\section{Conclusion}

The association between TCE exposure and kidney cancer should be definite according to epidemiologic studies. Although the findings from the cohort studies were inconsistent, the results from the case-control studies were consistent. Considering the limitations of cohort studies and the low prevalence of kidney cancer in those studies, the results of the well-designed case-control studies could be more useful for evaluating the causal association between TCE exposure and kidney cancer risk. The study subjects of the cohort studies were restricted to a few jobs or industries (i.e., aerospace workers or workers using TCE in the United Sates and Denmark) and exposure levels were measured based on the JEM, which can possible lead to the misclassification of exposure. According to the results from the metaanalyses and case-control studies, an increased risk for the exposure group and a dose-response relationship was identified using various exposure measures, such as cumulative exposure level, exposure duration, peak exposure, or JEM. Therefore, the epidemiologic evidence for the causal relationship between TCE exposure and kidney cancer could be sufficient.

In Korea, TCE remains a widely used chemical by various manufacturers. Occupational physicians should remember that past exposure levels of TCE could have been very high in patients when evaluating work-related causes of kidney cancer. TCE exposure levels have been as high as $>100 \mathrm{ppm}$ in some studies; plating, cleaning, or degreasing were common high-risk jobs for TCE exposure. Furthermore, the exposure level for manual jobs could be higher than automated jobs. The peak exposure level of TCE could also be considered an important variable due to the possibility of carcinogenesis, which is related to high dose phenomenon.

In summary, TCE is a widely used chemical and the incidence of kidney cancer has increased with the development of novel diagnostic techniques. Therefore, the construction of a JEM, case-control studies to evaluate risk factors associated with TCE exposure, and proper preventive policies are necessary. This review could be a comprehensive reference for evaluating the relationship between work-related TCE exposure and kidney cancer in Korea.

\section{Competing interests \\ The authors declared that they have no competing interests.}

\section{Authors' contributions}

IK: The first author of this article. She designed this research, collected and interpreted the data, prepared the draft of this manuscript, and approved the final version of the manuscript. $J \mathrm{H}$ : He reviewed and interpreted the epidemiologic articles and revised the draft of this manuscript, and approved the final version of the manuscript. JHL: He collected and reviewed the exposure status related report or papers and prepared the draft of the manuscript. KY: He collected and analyzed the exposure measurement data, revised the draft of this manuscript, and approved the final version of the manuscript. JR: The corresponding author of this article. He suggested the design of this research, interpreted data, revised the draft of this manuscript, and approved the final version of the manuscript.

\section{Acknowledgments}

This review was the part of study of Korean Society of Occupational and Environmental Medicine supported by Ministry of Employment and Labor.

\section{Author details}

${ }^{1}$ Department of occupational health, Yonsei University Graduate School of Public Health, Seoul, Korea. ${ }^{2}$ Institutes for Occupational Health, Yonsei 
University College of Medicine, Seoul, Korea. ${ }^{3}$ Department of occupational health, Seoul National University Graduate School of Public Health, Seoul, Korea. ${ }^{4}$ Occupational Safety and Health Research Institute, Korea Occupational Safety and Health Agency, Ulsan, Korea. ${ }^{5}$ Department of Preventive Medicine, Yonsei University College of Medicine, Seoul, Korea.

Received: 15 May 2014 Accepted: 21 May 2014

Published: 3 June 2014

\section{References}

1. NIOSH: Special Occupational Hazard Review with Control Recommendations Trichloroethylene. U.S: Dept. of Health Education and Welfare Public Health Services; 1978:1-59.

2. Dekant $W$, Metzler M, Henschler D: Novel metabolites of trichloroethylene through dechlorination reactions in rats, mice and humans. Biochem Pharmaco 1984, 33(13):2021-2027.

3. Guha N, Loomis D, Grosse Y, Lauby-Secretan B, El Ghissassi F, Bouvard V, Benbrahim-Tallaa L, Baan R, Mattock H, Straif K, International agency for research on cancer monograph working group: Carcinogenicity of trichloroethylene, tetrachloroethylene, some other chlorinated solvents, and their metabolites. Lancet Oncol 2012, 13(12):1192-1193.

4. Korea Occupational Safety and Health Agency: A kidney cancer case developed in automobile manufacturing industry. http://www.kosha.or.kr/ www/boardView.do? contentld=354838\&menuld=547\&boardType=A2

5. The Korea Central Cancer Registry, National Cancer Center: Annual Report of Cancer Statistics in Korea in 2011, Ministry of Health and Welfare. 2013:19-26 [http://ncc.re.kr/manage/manage03_033_view.jsp?bbsnum=295\&hSelSearch= \&hTxtKeyword=\&current_page $=1 \&$ \&d=null]

6. McCredie M, Ford JM, Stewart JH: Risk factors for cancer of the renal parenchyma. Int J Cancer 1988, 42:13-16.

7. Christensen PJ, Craig JP, Bibro MC, O'Connell KJ: Cysts containing renal cell carcinoma in von Hippel-Lindau diseases. J Urol 1982, 128:798-800.

8. IARC: List of Classifications by Cancer Sites with Sufficient or Lited Evidence in Human, Volumes 1 to 109. [http://monographs.iarc.fr/ENG/Classification/Table4.pdf]

9. Korea Occupational Safety and Health Agency: National working environment survey of manufacturing industry. Incheon 2004, 2005:183-189.

10. Cho HY, Cho SH, Ryoo JJ, Kim BG, Park S, Kang SK: A survey on the status of using trichloroethylene (TCE) in Korea. J Korean Soc Occup Environ Hyg 2007, 17(3):254-260.

11. Paik NW, Choi YS, Meng KH: Trichloroethylene poisoning in degreasing process of an electric appliances manufacturing. Korean J Occup Health 1970, 9(2):4-8.

12. Kim HA, Lee KM: Urinary excretion of total trichloro-compounds and air trichloroethylene concentration in trichloroethylene related workers. Korean J Occup Health 1989, 28(1):9-13.

13. Kim CY, Cho CJ, Kim YH, Park DY, Paik NW, Kim HA, Lee KM: Trichloroethylene exposure of workers employed in degreasing process of metal manufacturing. Korean J Occup Health 1989, 28(4):126-137.

14. Lee KH, Paik NW: A study on worker exposure to trichlorethylene and emission factor for degreasers in plating plants. J Korean Soc Occup Environ Hyg 1993, 3(1):3-13.

15. Jeon HS, Kim HW: The relationship between airborne trichloroethylene concentrations and total trichloro - compounds and trichloroacetic acid in urine. J Korean Soc Occup Environ Hyg 1994, 4(1):7-16.

16. Kang SK, Cho YS, Moon YH: Brain stem auditory evoked potential and R-R interval analysis of the workers exposed to trichloroethylene. Korean $J$ Occup Environ Med 1995, 7(1):111-119.

17. Scott CS, Jinot J: Trichloroethylene and cancer: systematic and quantitative review of epidemiologic evidence for identifying hazards. Int J Environ Res Public Health 2011, 8:4238-4272.

18. Karami S, Lan $\mathrm{Q}$, Rothman N, Stewart PA, Lee KM, Vermeulen R, Moore LE: Occupational trichloroethylene exposure and kidney cancer risk: a meta-analysis. Occup Environ Med 2012, 69(12):858-867.

19. Bruckner JV. Anand SS, Warren DA: Toxic Effects of Solvents and Vapors. In The Basic Science of Poisons. InCasarett \& Doull's Toxicology: Klaassen CD. McGraw-Hill Education; 2013:1031-1130.

20. Zhao Y, Krishnadasan A, Kennedy N, Morgenstern H, Ritz B: Estimated effects of solvents and mineral oils on cancer incidence and mortality in a cohort of aerospace workers. Am J Ind Med 2005, 48:249-258.

21. Raaschou-Nielsen O, Hansen J, McLaughlin JK, Kolstad H, Christensen JM, Tarone RE, Olsen JH: Cancer risk among workers at Danish companies using trichloroethylene: a cohort study. Am J Epidemiol 2003, 158(12):1182-1192.

22. Morgan RW, Kelsh MA, Zhao K, Heringer S: Mortality of aerospace workers exposed to trichloroethylene. Epidemiology 1998, 9:424-431.

23. Boice JD Jr1, Marano DE, Cohen SS, Mumma MT, Blot WJ, Brill AB, Fryzek JP, Henderson BE, McLaughlin JK: Mortality among Rocketdyne workers who tested rocket engines, 1948-1999. J Occup Environ Med 2006, 48:1070-1092

24. Moore LE, Boffetta P, Karami S, Brennan P, Stewart PS, Hung R, Zaridze D, Matveev V, Janout V, Kollarova H, Bencko V, Navratilova M, SzeszeniaDabrowska N, Mates D, Gromiec J, Holcatova I, Merino M, Chanock S, Chow WH, Rothman N: Occupational trichloroethylene exposure and renal carcinoma risk: evidence of genetic susceptibility by reductive metabolism gene variants. Cancer Res 2010, 70:6527-6536.

25. Charbotel B, Fevotte J, Hours M, Martin JL, Bergeret A: Case-control study on renal cell cancer and occupational exposure to trichloroethylene. Part II: Epidemiological aspects. Ann Occup Hyg 2006, 50:777-787.

26. Bruning T, Pesch B, Wiesenhutter B, Rabstein S, Lammert M, Baumuller A, Bolt HM: Renal cell cancer risk and occupational exposure to trichloroethylene: results of a consecutive case-control study in Arnsberg, Germany. Am J Ind Med 2003, 43(3):274-285.

27. Pesch B, Haerting J, Ranft U, Klimpel A, Oelschlägel B, Schill W: Occupational risk factors for renal cell carcinoma: agent-specific results from a case-control study in Germany. MURC Study Group. Multicenter urothelial and renal cancer study. Int J Epidemiol 2000, 29(6):1014-1024.

28. Goeptar AR, Commandeur JNM, van Ommen B, van Bladeren PJ, Vermeulen NPE: Metabolism and kinetics of trichloroethylene in relation to carcinogenicity. Relevance of the mercapturic acid pathway. Chem Res Toxicol 1995, 8:3-21.

doi:10.1186/2052-4374-26-12

Cite this article as: Kim et al.: The Relationship between the Occupational Exposure of Trichloroethylene and Kidney Cancer. Annals of Occupational and Environmental Medicine 2014 26:12.

\section{Submit your next manuscript to BioMed Central and take full advantage of:}

- Convenient online submission

- Thorough peer review

- No space constraints or color figure charges

- Immediate publication on acceptance

- Inclusion in PubMed, CAS, Scopus and Google Scholar

- Research which is freely available for redistribution 